\title{
Hylotelephium spectabile, a New Host for Carnation Tortrix Moth (Cacoecimorpha pronubana) and Molecular Characterization in Greece
}

\author{
Konstantinos B. Simoglou ${ }^{1, * \mathbb{D}}$, Dimitrios N. Avtzis ${ }^{2}$, Joaquín Baixeras ${ }^{3}$, Ioanna Sarigkoli ${ }^{1}$ \\ and Emmanouil Roditakis $4, * \mathbb{D}$ \\ 1 Department of Quality and Phytosanitary Inspections, Rural Economy \& Veterinary Directorate of Drama, \\ 66133 Drama, Greece; sarigkolii@pamth.gov.gr \\ 2 Forest Research Institute, Hellenic Agricultural Organization Demeter, Vassilika, 57006 Thessaloniki, Greece; \\ dimitrios.avtzis@fri.gr \\ 3 Institut Cavanilles de Biodiversitat i Biologia Evolutiva, Universitat de València, Carrer Catedràtic José, \\ 46980 Paterna, Spain; joaquin.baixeras@uv.es \\ 4 Department of Agriculture, School of Agricultural Sciences, Hellenic Mediterranean University, \\ 71410 Heraklion, Greece \\ * Correspondence: kbsimoglou@outlook.com (K.B.S.); eroditakis@hmu.gr (E.R.)
}

check for

updates

Citation: Simoglou, K.B.; Avtzis, D.N.; Baixeras, J.; Sarigkoli, I.; Roditakis, E. Hylotelephium spectabile, a New Host for Carnation Tortrix Moth (Cacoecimorpha pronubana) and Molecular Characterization in Greece. Insects 2021, 12, 245. https:// doi.org/10.3390/insects12030245

Academic Editor: Brian T. Forschler

Received: 15 January 2021

Accepted: 13 March 2021

Published: 15 March 2021

Publisher's Note: MDPI stays neutral with regard to jurisdictional claims in published maps and institutional affiliations.

Copyright: (c) 2021 by the authors. Licensee MDPI, Basel, Switzerland. This article is an open access article distributed under the terms and conditions of the Creative Commons Attribution (CC BY) license (https:// creativecommons.org/licenses/by/ $4.0 /)$.
Simple Summary: Hylotelephium spectabile (Saxifragales, Crassulaceae), a widespread ornamental plant was found infested by larvae of Cacoecimorpha pronubana (Lepidoptera, Tortricidae) a highly polyphagous pest of a wide range of crop, as well as ornamental plants. To the best of our knowledge, this finding suggests that $H$. spectabile should be considered a new host plant for C. pronubana. Moreover, molecular characterization of the Greek pest population place it along with European species clade.

Abstract: Cacoecimorpha pronubana (Hübner) (Lepidoptera, Tortricidae) is a highly polyphagous pest of a wide range of crop and ornamental plants. It is of Mediterranean origin and widespread in European and Mediterranean Plant Protection Organization (EPPO) region. For the first time, infestations of Hylotelephium spectabile (Boreau) Ohba (syn.: Sedum spectabile Boreau) (Saxifragales, Crassulaceae) ornamental plants by C. pronubana larvae, in private gardens in urban area of Drama, Greece, were found. Species identification was conducted based on morphology of female genitalia. In addition, due to reports on occurrence of cryptic C. pronubana species within Europe, DNA barcoding was carried out to determine the molecular status of the pest. This communication reports a new host of C. pronubana and places the Greek pest population along with European species clade.

Keywords: Cacoecimorpha pronubana; Hylotelephium spectabile; molecular characterization; new host

\section{Introduction}

The carnation tortrix moth, Cacoecimorpha pronubana (Hübner) (Lepidoptera, Tortricidae) is a highly polyphagous and locally important pest of a wide range of crop plants. In addition, $C$. pronubana infests also ornamental plants (Table 1). Usually considered a typical Mediterranean element, C. pronubana is widely distributed among most EPPO member-countries [1] and is locally common across Europe to Asia Minor, North Africa, but it is also recorded from South Africa as well as North America [2-7]. In Greece the species occurs both in mainland [7] and on the island of Crete [8]. 
Table 1. Non extensive host-plant list of Cacoecimorpha pronubana.

\begin{tabular}{|c|c|c|c|c|}
\hline Host Category & Common Name & Scientific Name & Botanic Family & References \\
\hline \multirow{8}{*}{ Crop plants } & strawberry & Fragaria $\times$ ananassa Duchesne & Rosaceae & \multirow{8}{*}[3,6,9]{} \\
\hline & almond & Prunus dulcis (Mill.) D.A. Webb & Rosaceae & \\
\hline & cherry & Prunus avium L. & Rosaceae & \\
\hline & apple & Malus domestica Borkh. & Rosaceae & \\
\hline & raspberry & Rubus spp. & Rosaceae & \\
\hline & grapevine & Vitis vinifera $\mathrm{L}$. & Vitaceae & \\
\hline & citrus & Citrus spp. & Rutaceae & \\
\hline & olive & Olea europaea L. & Oleaceae & \\
\hline \multirow{16}{*}{ Ornamental plants } & carnation & Dianthus spp. & Caryophyllaceae & \multirow{15}{*}[10,11]{} \\
\hline & bay laurel & Laurus nobilis L. & Lauraceae & \\
\hline & cypress & Cupressus spp. & Cupressaceae & \\
\hline & broom & Cytisus spp. & Fabaceae & \\
\hline & daphne & Daphne spp. & Thymeleaceae & \\
\hline & false acacia & Robinia pseudoacacia L. & Fabaceae & \\
\hline & fuchsia & Fuchsia spp. & Onagraceae & \\
\hline & spider flower & Grevillea spp. & Proteaceae & \\
\hline & honeysuckle & Lonicera spp. & Caprifoliaceae & \\
\hline & St. John's wort & Hypericum spp. & Hypericaceae & \\
\hline & ivy & Hedera spp. & Araliaceae & \\
\hline & Japanese spindle & Euonymus japonicus Thunb. & Celastraceae & \\
\hline & privet & Ligustrum vulgare L. & Oleaceae & \\
\hline & laurustinus & Viburnum tinus L. & Adoxaceae & \\
\hline & Japanese laurel & Aucuba japonica Thunb. & Garryaceae & \\
\hline & Cape sundew & Drosera capensis L. & Droseraceae & [12] \\
\hline
\end{tabular}

Hylotelephium spectabile (Boreau) Ohba (syn.: Sedum spectabile Boreau) (Saxifragales, Crassulaceae) is an ornamental plant species that is widely distributed throughout the warm and temperate zones, originating from Korea and Northern China [13]. It is approximately $45 \mathrm{~cm}$ high, glaucous green in color and bears large, flat-topped, pink-purple inflorescences that attract nectar-feeding insects (particularly butterflies) hence it is commonly known as butterfly stonecrop. Hylotelephium spectabile has sparsely toothed leaf margins and flower stamens longer than petals, which differentiates it from other species in the genus [14].

In this study, we report a carnation tortrix infestation on butterfly stonecrop plants. Based on an extensive literature review, to the best of our knowledge no Crassulaceae member-plants have been previously reported as host of this species. Our results support that the particular plant species can be considered a new host of $C$. pronubana $[6,15]$.

\section{Identification}

In mid-August 2020, caterpillars of an unknown species have been detected feeding on potted butterfly stonecrop plants located in private gardens in the broader area of Drama (Region of Eastern Macedonia and Thrace, Northern Greece). Infestation had caused considerable damage on foliage as well as on blossoms, reducing the ornamental/aesthetical value of the butterfly stonecrop plants. Leaves of the infested plants were chewed and knitted together with silken webbing, in which feeding caterpillars inhabited (Figure 1a). This observation is in line with the first description of carnation tortrix by Fisher (1924) [16], who stated that caterpillars older than the 3rd instar feed under a dense silken cover, remaining completely hidden in the rolled leaf or leaves from which they are feeding. 


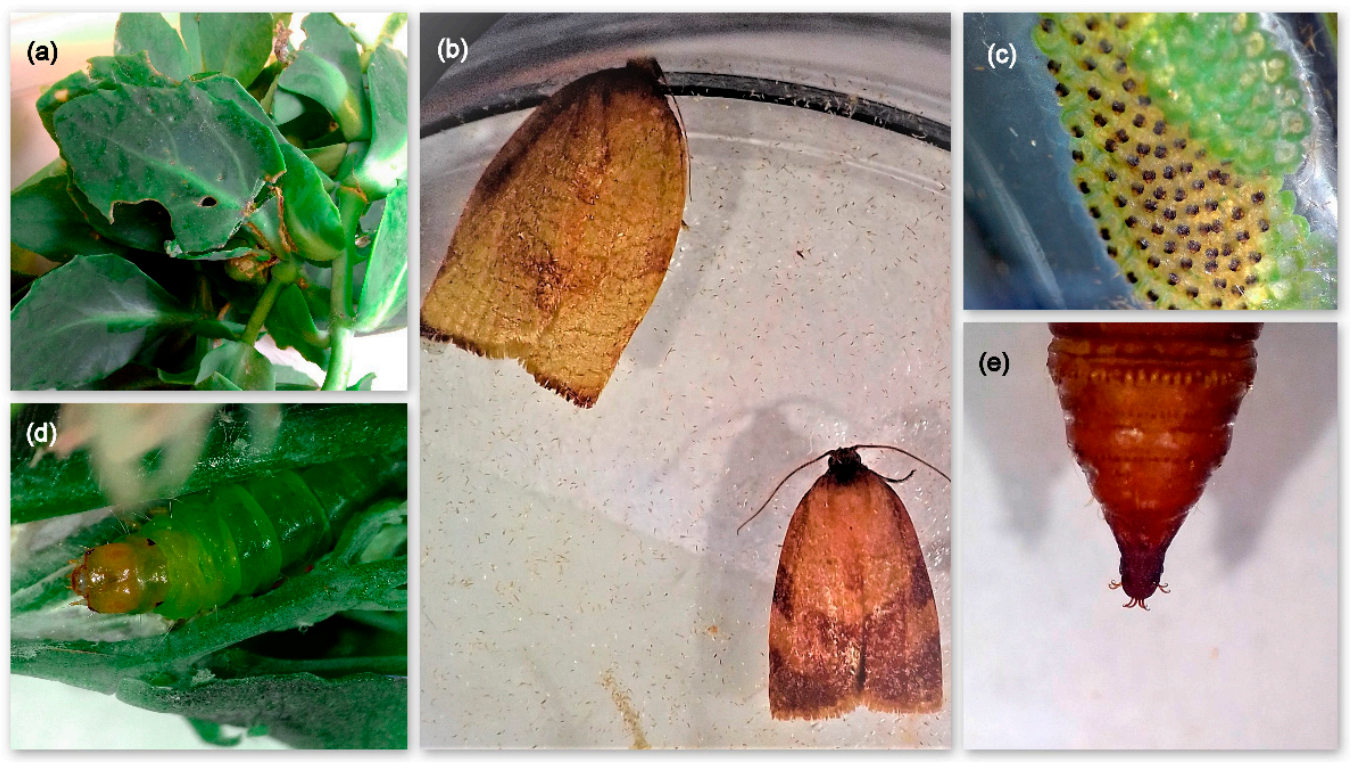

Figure 1. (a) Butterfly stonecrop plant leaves, chewed and knitted together by Cacoecimorpha pronubana larvae; (b) Female (left) and male (right) individuals of Cacoecimorpha pronubana; (c) Eggs mass of Cacoecimorpha pronubana laid on petri-dish; (d) Cacoecimorpha pronubana larva on butterfly stonecrop plant inflorescence; (e) Cacoecimorpha pronubana pupa cremaster with 8 hooked bristles.

Larvae collected in the field were reared in the laboratory of the Department of Quality and Phytosanitary Inspections of Drama (Drama, Greece). The external morphological characters of eggs, larvae, pupae and the emerged adults resembled those of C. pronubana $[3,11,16,17]$ (Figure $1 \mathrm{~b}-\mathrm{e}$ ). Morphological identification based on female genitalia was conducted by one of the authors (J.B.) and compared with literature reports and collection samples. Further on, due to reports on occurrence of cryptic C. pronubana species within Europe [18], DNA was extracted from the specimens in order to proceed with DNA barcoding. To do that, two individuals (4th instar caterpillars) were stored in 95\% ethanol and posted for analysis to the Laboratory of Forest Entomology (Forest Research Institute, Hellenic Agricultural Organization Demeter) (Thessaloniki, Greece). Total genomic DNA was extracted from each individual separately, using PureLink ${ }^{\circledR}$ Genomic DNA kit (Invitrogen, Waltham, MA, USA) and following the manufacturers' instructions modified during the tissue grinding process [19]. Polymerase Chain Reaction (PCR) was run in $25 \mu \mathrm{L}$ volumes with primers $\mathrm{LCO} / \mathrm{HCO}$ that amplify a 658bp-fragment of mtDNA's Cytochrome Oxidase subunit I gene (COI) [20]. PCR procedure is provided in Avtzis et al., (2021) [19]. The purification of PCR products was performed with PureLink ${ }^{\circledR}$ PCR Purification Kit (Invitrogen) following the manufacturer's protocol and purified products were sequenced in the automated sequencer ABI3730XL of CeMIA Company (Larisa, Greece), using the same primers as in PCR. Finally, sequences were initially visualized with Chromas Lite ${ }^{\circledR}$ version 2.01 (Technelysium Pty Ltd., South Brisbane, Australia) and after removing the ambiguous nucleotides at both ends of the sequences, a final product of $443 \mathrm{bp}$ long was obtained for each individual. These sequences were then blasted in the NCBI GenBank database (https: / / www.ncbi.nlm.nih.gov / genbank/ (accessed on 13 March 2021)), placing them among the sequences of $C$. pronubana deposited there. In particular, both these sequences were 100\% identical with C. pronubana from France (Accession Number: KX041548) and Italy (Accession Number LC031966), and 99.77\% similar with the sequences from the United Kingdom (Accession Number: KX043977), Germany (Accession Number: KX041034) and Italy (Accession Number LC031971). Given the distinct separation that has been previously revealed among the populations of $C$. pronubana worldwide [18], we compiled all the available $C$. pronubana sequences, deposited both in NCBI (see Accession Numbers above) and BOLD (BOLD BINs: AAD3477 and AAL5782) into an integrated large dataset and constructed a Neighbor-Joining phylogenetic tree. To do that, we used MEGA6 [21], em- 
ploying K-2P distances with 500 bootstrap replicates, and rooted the tree with a sequence of a closely related tortricid species (Accession Number MK019304.1). Greek sequences were apparently assigned to the clade that contains all European C. pronubana sequences, remaining distinctly separated from those of Spain (Figure 2). Interestingly, divergence between Spanish and Greek (and the other European) sequences is found to be much higher $(>3.5 \%)$ than commonly expected for intraspecific divergence within tortricid species (e.g., Anarsia lineatella / Grapholita molesta [22]). Nevertheless, as deep intraspecific barcode divergences have already been detected in a few more tortricid species as well [23], this finding should be further investigated to conclude whether this pattern is an artifact of non-continuous distribution or by-product of mitochondrial evolution [24].

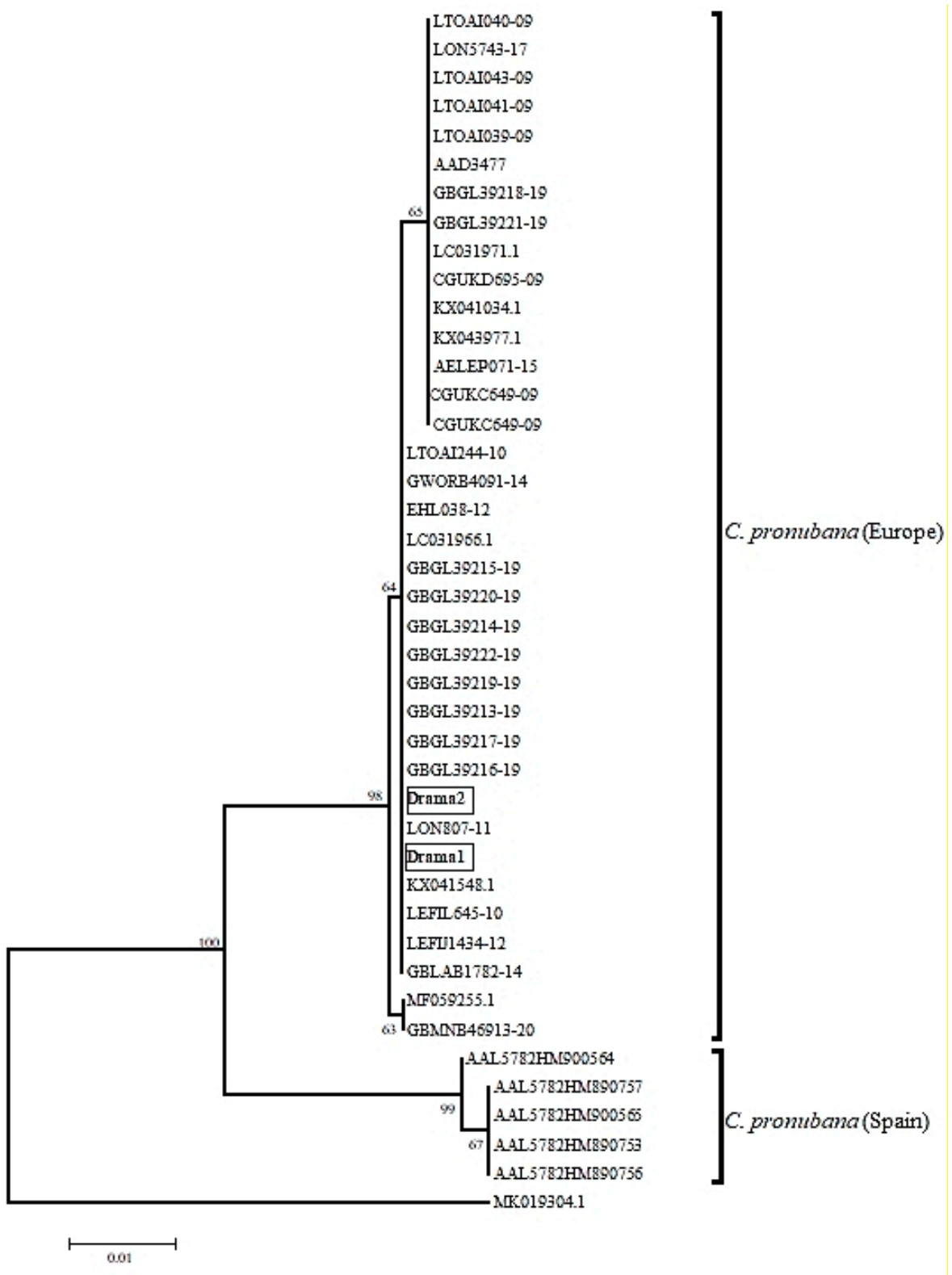

Figure 2. Rooted NJ phylogenetic tree (500 bootstrap replicates / K-2P) that contains the two C. pronubana sequences from Greece (Drama 1 and 2) and all the available C. pronubana sequences in NCBI and BOLD databases. Scale-bar stands for $0.01 \mathrm{~K}-2 \mathrm{P}$ distance.

\section{Biological and Taxonomic Notes of Cacoecimorpha pronubana}

Cacoecimorpha pronubana adults are nocturnal and males are much more active than females with a flight that is erratic and agitated [16]. Cacoecimorpha Obraztsov 1954 is 
a monotypic tortricid genus with adult females having a wingspan of 18-22 mm, with pale orange brown forewings that are reticulated with darker brown coloration, while hindwings are mainly orange. Adult males are generally smaller (wingspan of 12-17 mm) and their forewings are orange brown with reddish-brown and purplish-black markings while their hindwings are bright orange with blackish border (Figure 1a). Both male and female genitalia give key diagnostic characters $[25,26]$. The eggs are light green and are laid in egg-masses [3] in which around 200 eggs are overlapping and surrounded by a mucilaginous substance [16] (Figure 1c). Caterpillars are olive to bright green with slightly paler pinacula and a length that can reach up to $20 \mathrm{~mm}$. The head is greenish yellow or yellowish brown, with dark brown marks and the prothoracic and anal plates have green coloration, with dark brown marks (Figure 1d). The anal comb is green and is usually 6-pronged. Pupae are 9-12 mm long, with brownish black to black colors. They have elongated and tapered cremaster, with 8 strong, hooked bristles [3] (Figure 1e). In Europe, the carnation tortrix moth has two to five generations per year, with adults emerging from April to October, or even later. The eggs are laid on the leaves and hatch about 15-20 days later [3]. The duration of egg-laying of a single female is approximately 12-14 days during which 7 or 8 egg-masses are laid [16]. Caterpillars feed on leaves, inflorescence and fruits and go through seven instars. Pupation takes place in rolled leaves or amongst webbed foliage and lasts approximately 13-17 days. First instars usually overwinter sheltering on the foodplant inside silken hibernacula. However, under favorable conditions feeding may continue through winter and then all stages of the pest may be found together $[3,16]$.

\section{Conclusions}

Hereby, a new host plant was detected for C. pronubana. Therefore, the pest list of butterfly stonecrop, $H$. spectabile, has to be updated, including the carnation tortrix moth. Our findings can significantly contribute to the accurate pest identification for ornamentals in future and of butterfly stonecrop, in particular. Since both the pest and its new host are wide spread, future infestations or outbreaks can occur anywhere in the world, thus current information will facilitate rapid and appropriate pest management actions in the future. In addition, DNA barcoding confirmed the findings of Gilligan et al. (2020) [18], placing Greek carnation tortrix moth population along with European species clade, establishing further the knowledge on C. pronubana in Europe.

Author Contributions: Case identification and reporting, I.S. and K.B.S.; collection, rearing, symptoms and insect photography, K.B.S.; species identification, D.N.A. and J.B.; writing-original draft preparation, K.B.S.; writing-review and editing E.R., D.N.A. and J.B.; co-ordination E.R. All authors have read and agreed to the published version of the manuscript.

Funding: This research received no external funding.

Institutional Review Board Statement: Not applicable.

Data Availability Statement: All data are included in the manuscript.

Conflicts of Interest: The authors declare no conflict of interest.

\section{References}

1. Suffert, M. Re-evaluation of EPPO-listed pests. EPPO Bull. 2012, 42, 181-184. [CrossRef]

2. Kaçar, G.; Ulusoy, M.R. A new pest of olive trees: Carnation tortrix, Cacoecimorpha pronubana (Hübner), 1796-1799 (Lepidoptera: Tortricidae) in the Eastern Mediterranean Region of Turkey. Turk. J. Entomol. 2008, 32, 211-223, (English Abstract). Available online: https: / / dergipark.org.tr/en/download/article-file/ 65044 (accessed on 20 December 2020).

3. Alford, D.V. Pests of Fruit Crops: A Colour Handbook, 2nd ed.; CRC Press/Taylor \& Francis Group: Boca Raton, FL, USA, 2014; pp. 266-267.

4. Pencheva, A.; Yovkova, M. New data on alien insect pests of ornamental plants in Bulgaria. For. Ideas 2016, 22, 17-33. Available online: https: / / forestry-ideas.info/issues /issues_Index.php?pageNum_rsIssue=0\&totalRows_rsIssue=9\&journalFilter=55 (accessed on 20 December 2020).

5. Imre, F. Hedera helix L. a new larval foodplant for Cacoecimorpha pronubana (Hübner, [1796-99]) in Hungary (Lepidoptera: Tortricidae). Microlepidopterahu 2019, 15, 29-34, (English Abstract). [CrossRef] 
6. EPPO Global Database. Available online: https://gd.eppo.int (accessed on 18 December 2020).

7. Aarvik, L.E. Fauna Europaea: Tortricidae. In Fauna Europaea: Lepidoptera, Moths. Fauna Europaea Version 2017.06; Karsholt, O., van Nieukerken, E.J., Eds.; Fauna Europaea: Berlin, Germany, 2013; Available online: https://fauna-eu.org (accessed on 18 December 2020).

8. Nel, J.; Nel, A. Contribution to the knowledge of the Lepidoptera of the Crete Island (Greece) (Lepidoptera). Le Bull. SEF 2003, $108,277-282$.

9. Carvalho, P.; Franco, J.C.; Aguiar, A.; Soares, A. Insect pests of citrus in Portugal. International Citrus Congress. In Proceedings of the International Society of Citriculture, Sun City, South Africa, 12-17 May 1996; pp. 613-618. Available online: https: / / www.researchgate.net/publication/233819663_Insect_pests_of_citrus_in_Portugal (accessed on 20 December 2020).

10. Alford, D.V. Pests of Ornamental Trees, Shrubs and Flowers: A Colour Handbook, 2nd ed.; Manson: London, UK, $2012 ;$ p. 263.

11. Hebert, P.D.N.; Cywinska, A.; Ball, S.L.; deWaard, J.R. Biological identifications through DNA barcodes. Proc. R. Soc. Lond. B 2003, 270, 313-321. [CrossRef] [PubMed]

12. Signorile, L. An unusual, new larval host-plant for Cacoecimorpha pronubana (Hübner, 1799) (Lepidoptera: Tortricidae). Ento-mol. Gaz. 2012, 63, 49-51.

13. Yang, C.; Qin, Y.; Sun, X.; Yuan, S.; Lin, H. Propagation of Sedum spectabile Boreau in Leaf Culture in Vitro. Not. Bot. Hort. Agrobot. Cluj. 2012, 40, 107. [CrossRef]

14. Stephenson, R. Sedum. Cultivated Stonecrops; Timber Press: Portland, OR, USA, 1994; p. 272.

15. Gilligan, T.M.; Baixeras, J.; Brown, J.W. T@RTS: Online World Catalogue of the Tortricidae (Ver. 4.0). Available online: http: / / www.tortricid.net/catalogue.asp (accessed on 22 December 2020).

16. Fisher, R.C. The life-history and habits of Tortrix pronubana, HB, with special reference to the larval and pupal stages. Ann. Appl. Biol. 1924, 11, 395-447. [CrossRef]

17. Alford, D.V. A Textbook of Agricultural Entomology, 1st ed.; Blackwell Science: Oxford, MA, USA, 1999; p. 214.

18. Gilligan, T.M.; Brown, J.W.; Baixeras, J. Immigrant Tortricidae: Holarctic versus Introduced Species in North America. Insects 2020, 11, 594. [CrossRef] [PubMed]

19. Avtzis, D.N.; Markoudi, V.; Mizerakis, V.; Devalez, J.; Naka, G.; Poulakakis, N.; Petanidou, T. The Aegean Archipelago as cradle: Divergence of the glaphyrid genus Pygopleurus and phylogeography of P. foina. Syst. Biodivers 2021. under publication.

20. Folmer, O.; Black, M.; Hoeh, W.; Lutz, R.; Vrijenhoek, R. DNA primers for amplification of mitochondrial cytochrome c oxidase subunit I from diverse metazoan invertebrates. Mol. Mar. Biol. Biotech. 1994, 3, 294-299. Available online: https:/ /www.researchgate.net/publication/15316743_DNA_primers_for_amplification_of_mitochondrial_Cytochrome_C_ oxidase_subunit_I_from_diverse_metazoan_invertebrates (accessed on 20 December 2020).

21. Tamura, K.; Stecher, G.; Peterson, D.; Filipski, A.; Kumar, S. MEGA6: Molecular Evolutionary Genetics Analysis Version 6.0. Mol. Biol. Evol. 2013, 30, 2725-2729. [CrossRef] [PubMed]

22. Damos, P.; Bonsignore, C.P.; Gardi, F.; Avtzis, D.N. Phenological Responses and a Comparative Phylogenetic Insight of Anarsia Lineatella and Grapholita Molesta between Distinct Geographical Regions within the Mediterranean Basin. J. Appl. Entomol. 2014, 138, 528-538. [CrossRef]

23. Huemer, P.; Hebert, P.D.N.; Mutanen, M.; Wieser, C.; Wiesmair, B.; Hausmann, A.; Yakovlev, R.; Möst, M.; Gottsberger, B.; Strutzenberger, P.; et al. Large Geographic Distance versus Small DNA Barcode Divergence: Insights from a Comparison of European to South Siberian Lepidoptera. PLoS ONE 2018, 13, e0206668. [CrossRef]

24. Arthofer, W.; Avtzis, D.; Riegler, M.; Stauffer, C. Mitochondrial Phylogenies in the Light of Pseudogenes and Wolbachia: Re-Assessment of a Bark Beetle Dataset. ZooKeys 2010, 56, 269-280. [CrossRef] [PubMed]

25. Razowski, J. Tortricidae of Europe. Tortricinae and Chlidanotinae; Slamka: Bratislava, Slovakia, 2002; Volume 1, p. 247.

26. Chambon, J.P. Atlas des genitalia Males des lépidoptères Tortricidae France et Belgique; INRA Editions: Paris, France, $1999 ;$ p. 400. 